\title{
Benzothiazole Thioflavin T improves obesity-related symptoms in mice
}

\section{FATEMEH JALALVAND ${ }^{1 \#}$ \\ MAHSA M AMOLI' \\ PARICHEHREH YAGHMAEI ${ }^{1 *}$ \\ MASOUD KIMIAGAR ${ }^{3}$ \\ AZADEH EBRAHIM-HABIBI ${ }^{4 *}$ \\ ${ }^{1}$ Department of Biology, Science and Research Branch, Islamic Azad University, Tehran, Iran \\ * Present Address: Department of Biology, Malard Branch, Islamic Azad University, Malard, Tehran, Iran \\ 2 Endocrinology and Metabolism Research Center Endocrinology and Metabolism Clinical Sciences Institute, Tehran University of Medical Sciences Tehran, Iran \\ ${ }^{3}$ National Nutrition and Food Science Research Institute, Shahid Beheshti University of Medical Science, Tehran, Iran \\ ${ }^{4}$ Biosensor Research Center, Endocrinology and Metabolism Molecular-Cellular Sciences Institute Tehran University of Medical Sciences, Tehran, Iran}

\section{Correspondence:}

Azadeh Ebrahim-Habibi

e-mail: aehabibi@sina.tums.ac.ir, azadehabibi@yahoo.fr

Parichehreh Yaghmei:yaghmaei_p@srbiau.ac.ir

Keywords: Thioflavin T, obesity, adipocyte, leptin, adiponectin

Received August 26, 2015.

Revised April 12, 2016.

Accepted April 14, 2016.

\begin{abstract}
Background and Purposes: In order to counteract the obesity epidemics, novel therapeutics are needed. Thioflavin $T$ (ThT) is a benzothiazole used as an amyloid probe and has other properties such as anti-aging and antihyperglycemic effects. The current study aimed at investigating its effect on obesity.
\end{abstract}

Materials and Methods: A mouse model of obesity was generated by feeding male NMRI mice with a high fat diet (HFD) for 8 weeks. After this period, mice diet was switched to normal rodent diet, and ThT was orally administered with a $12 \mathrm{mg} / \mathrm{Kg}$ dose. The treatment effect was assessed on biochemical parameters, adipokines (adiponectin and leptin), total antioxidant capacity and TNF- $\alpha$. Histological investigation was made on samples taken from adipose tissue and liver.

Results and Conclusion: After receiving HFD, mice exhibited significantly increased body weight compared with a control group as well as well as abnormality in biochemical parameters. A significantly effective result was obtained on body weight, blood glucose, cholesterol and ALT serum levels which decreased in the treated group. ThT caused also a signifcant decrease in leptin levels and TNF- $\alpha$. Furthermore, the compound led to a reduction in the size of adipose tissue cells, as well as the number of lipid droplets in hepatic tissue. In conclusion, it is suggested that ThT possess an interesting potential for being used as an anti-obesity drug, especially when considering its previously reported effects as potential anti-diabetic and anti-ageing compound.

\section{INTRODUCTION}

$\mathrm{O}$ besity is associated with multiple issues such as type 2 diabetes and cardiovascular diseases (1) (2), is a component of metabolic syndrome, could affect intellectual performance (3), causes psychological disorders (4) and finally become life-threatening (5). An inflammatory component is also present, which has been related to the release of free fatty acids and inflammatory cytokines from the adipose tissue and could predispose to different pathologies including cancer (6). Obesity has a high prevalence, which has led to the use of the „epidemics” term, and a simple efficient remedy is still lacking (7). Previously used antiobesity drugs, such as orlistat and sibutramine, had modest clinical efficacy and serious side effects(8), while the newly approved drugs have still limited effect and may also need to be used alongside with lifestyle modification (9).

With regard to the necessity of finding compounds that could be proposed as new potential drugs, and based on a previous experiment 
that had shown the beneficial effect of thioflavin T (ThT) in an animal model of diabetes (10), the present study was designed in order to test the effect of ThT in mice fed with a high fat diet. Thioflavin $\mathrm{T}$ is a benzothiazole that has been widely used to characterize amyloid fibrils, which are ordered aggregated protein structures related to a variety of diseases (11).

\section{MATERIALS AND METHODS}

\section{Animals}

Male NMRI mice(six weeks old) weighing $25 \pm 5 \mathrm{~g}$ were obtained from the Razi Vaccine and Serum Institute, Karaj, Iran. Mice were exposed to a12-h light/dark cycle and the animal room had a constant temperature of 25 ${ }^{\circ} \mathrm{C}$. Mice were housed in the animal room in standard cages and allowed to adapt at for one week, after which they were randomly divided into two groups ( $\mathrm{n}=12$ in the control group and $n=24$ in the obese group). The control group was receiving standard rodent diet the obese group was receiving high-fat diet for eight weeks. The high-fat diet was prepared from a mix of $15 \mathrm{~g}$ of mouse pellet standard chow, $10 \mathrm{~g}$ of roasted ground nut, $10 \mathrm{~g}$ of milk chocolate and $5 \mathrm{~g}$ of sesame crackers. $20 \mathrm{~g}$ roasted sesame was added to ten-fold of these components, resulting into $18 \mathrm{~kJ} / \mathrm{g}$ energy content, and the obese group was fed $240 \mathrm{~g}$ creamy biscuits $(3644 \mathrm{~kJ})$ weekly. The normal group was allowed ad libitum access to standard chow, taking a total of $13 \mathrm{~kJ} / \mathrm{g}$ weekly (12). After eight weeks, all animals were given standard rodent diet, and the obese animals were divided into two groups: control obese and experimental group. The experimental group was treated with ThT $(12 \mathrm{mg} / \mathrm{kg} /$ day $)$ by oral gavage for eight weeks; ThT was dissolved in distilled water, and the dose was chosen based on previous results obtained in diabetic animals (10). The obese control group did not received any treatment Mice were weighed weekly during the 8 weeks of treatment. At the end of the experiment, the animals were anesthetized and sacrificed; blood samples were collected and immediately centrifuged at $1500 \mathrm{~g}$ for $10 \mathrm{~min}$ at $4^{\circ} \mathrm{C}$. Serums were then collected and stored at $4^{\circ} \mathrm{C}$ until further analyzes were made. The experimental protocol was approved by the Research and Ethics Committee of the Endocrinology and Metabolism Research Institute (EMRI) of Tehran University of Medical Sciences (code: EC-00245)in accordance with the international guidelines set out in the Guide for the Care and Use of Laboratory Animals (Institute of Laboratory Animal Resources, 1996).

\section{Biochemical parameters}

Serum levels of total cholesterol, triglyceride, HDL, ALT and AST were measured with the use of enzymatic methods (Pars Azmoon, Iran).Blood glucose levels were measured by a glucometer apparatus (ACCU-CHEK, Germany).Plasma adiponectin, TNF- $\alpha$ and leptin concentration were determined by ELISA (respectively R\&D Systems, USA; Enzo life Science, USA and ALPCO,USA). Plasma total antioxidant capacity (TAC) levels were measured by a colorimetric method (BioVision,USA).
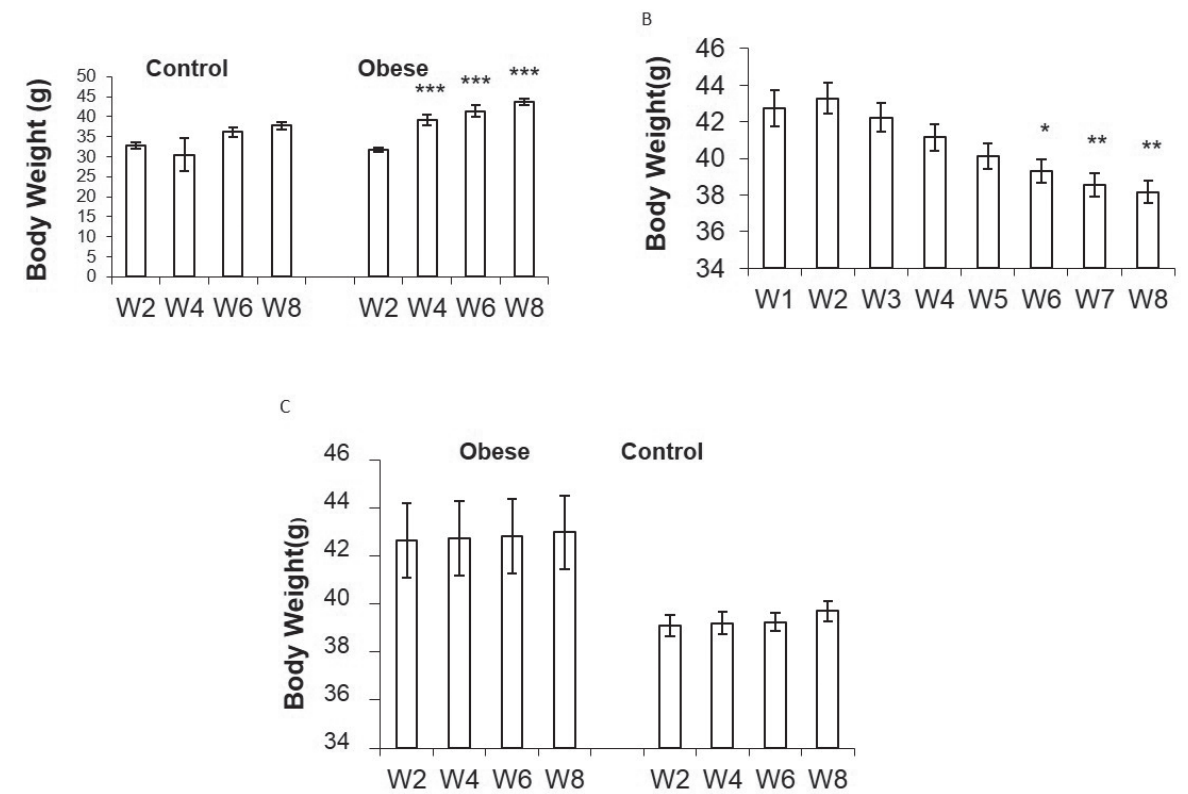

Fig. 1 A. Effect of receiving standard diet (control group) and high-fat diet (obese group) on mice body weight. W is the abbreviation used for "week". ${ }^{* *} p<0.001$ (compared within the same group, and with the second week). B. Effects of ThT treatment on body weight of obese mice. ${ }^{*} p<0.05$ : compared with W1 and W2; ** $<0.01$ : compared with W1, W2 and W3; ${ }^{* * *} p<0.001$ : compared with W1, W2 and W3. C. Control and untreated obese group mice weight changes during the second part of the experiment. This graph reports the same time period as Fig.1b. In all instances, data is shown as mean $\pm S D$. 


\section{Histological Studies}

Sample abdominal adipose tissue samples were taken and fixed in formalin and subsequently stained with hematoxylin and eosin (H\&E).

\section{Statistical Analysis}

The data were statistically analyzed by SPSS, with the use of ANOVA and Tukey's test. Values are reported as mean \pm SD and the level of significance set at $\mathrm{p}<0.05$.

\section{RESULTS}

\section{Body weight and blood glucose}

Mice that were receiving high-fat diet gained more weight than the control group, and the difference was clearly significant from the $4^{\text {th }}$ week onward (Fig.1a). Treating these mice (termed „obese") with ThT resulted in a marked weight loss (Fig.1b), while at the same period, the untreated obese and the control group mice did not show any significant weight change (Fig. 1c).

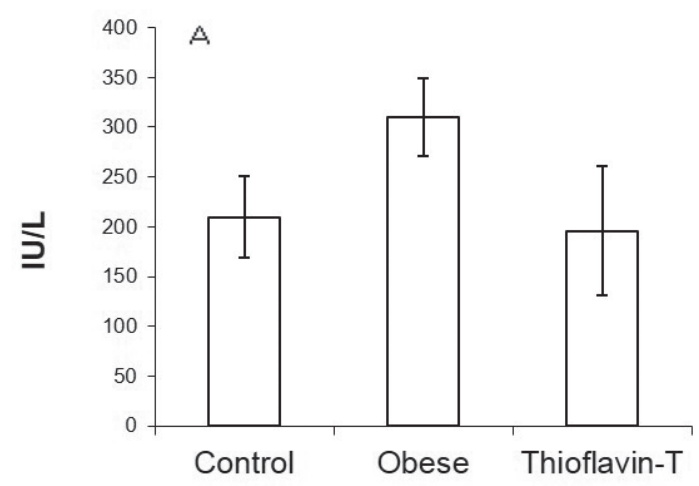

Table 1. Effects of ThT treatment on blood glucose (mg/dl) levels in mice at the start of the experiment (week 0), and at weeks 4 and 8. Data is shown as mean $\pm S D$. * $p<0.05$, obtained by comparing ThTtreated and obese groups.

\begin{tabular}{|cccc|}
\hline Groups & $\begin{array}{c}\text { Blood glucose } \\
(\mathrm{mg} / \mathrm{dl}) \\
\text { Week 0 }\end{array}$ & $\begin{array}{c}\text { Blood glucose } \\
(\mathrm{mg} / \mathrm{dl}) \\
\text { Week } 4\end{array}$ & $\begin{array}{c}\text { Blood glucose } \\
(\mathrm{mg} / \mathrm{dl}) \\
\text { Week } 8\end{array}$ \\
\hline Control & $112.66 \pm 11.56$ & $141 \pm 2.08$ & $166 \pm 3.60$ \\
Obese & $185 \pm 30.17$ & $152.66 \pm 3.17$ & $165.33 \pm 12.25$ \\
ThT & $154.33 \pm 4.48$ & $126 \pm 16.56$ & $113 \pm 11.84^{*}$ \\
\hline
\end{tabular}

The high-fat diet resulted into elevated blood glucose levels in mice compared to the control group (Table 1). In the eighth week of treatment, ThT-treated mice showed significantly lower levels of blood glucose $(p<0.05)$ in comparison with obese and control groups at week 8 of the experiment.

\section{ALT and AST}

At the end of the experiment (16 weeks), AST and ALT levels were measured. In the untreated obese group, only

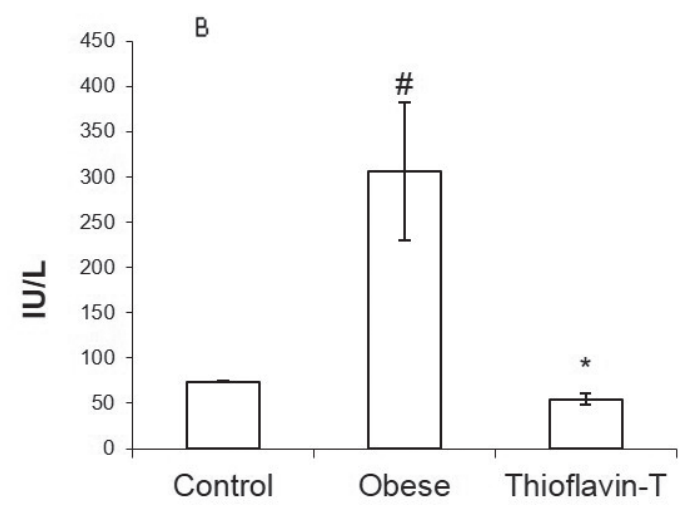

Figure 2. AST (a) and ALT (b) levels in the control, untreated obese, and ThT-treated mice (shown as Thioflavin-T in the graph). Data is shown as mean $\pm S D$. $\# p<0.05$ compared with the control group. ${ }^{*} p<0.05$ compared with the untreated obese group.

$\mathrm{A}$

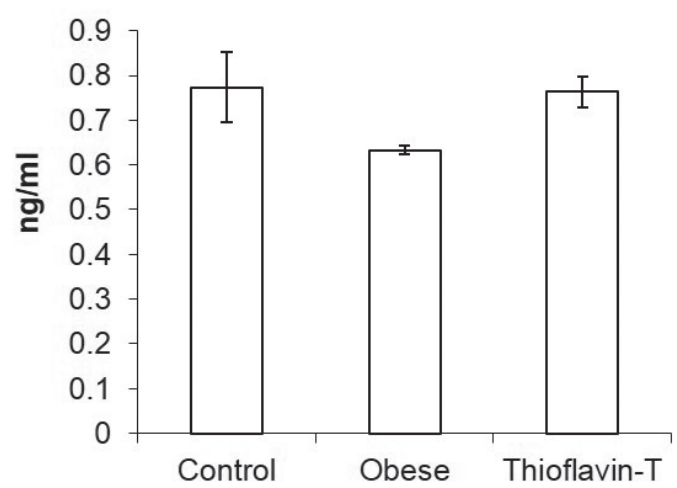

B

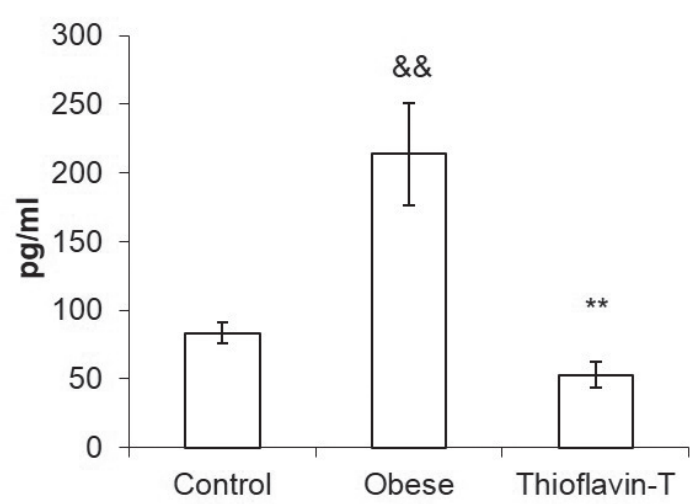

Figure 3. Adiponectin (a) and leptin (b) levels in the control, untreated obese, and ThT-treated mice (shown as Thioflavin-T in the graph). Data is shown as mean $\pm S D$. \& \& $p<0.001$ compared with the control group; ${ }^{* *} p<0.001$ compared with the untreated obese group. 
A

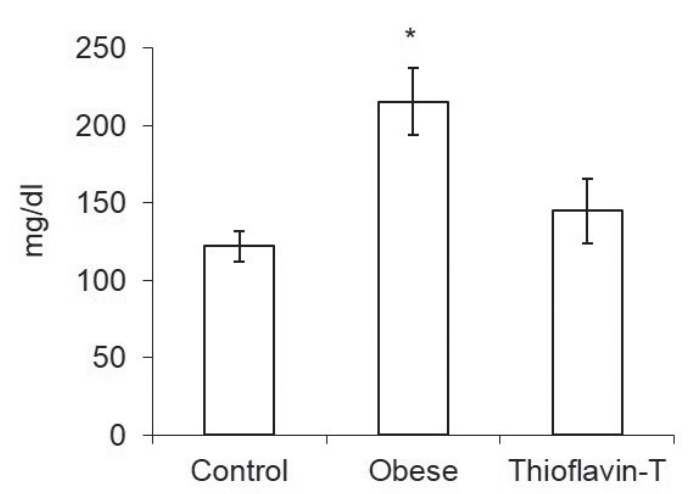

B

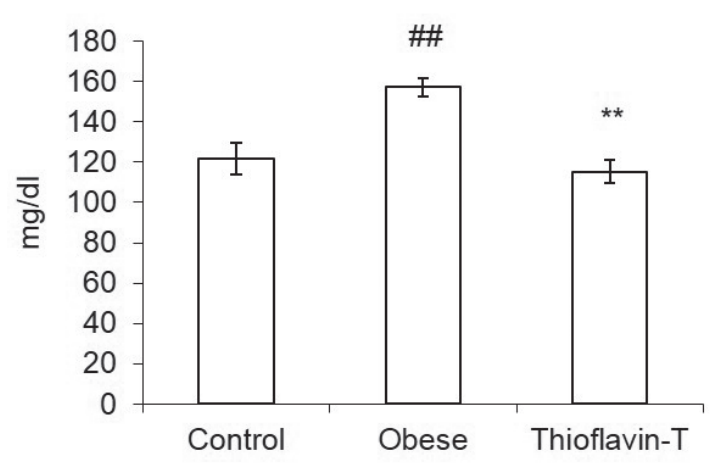

C

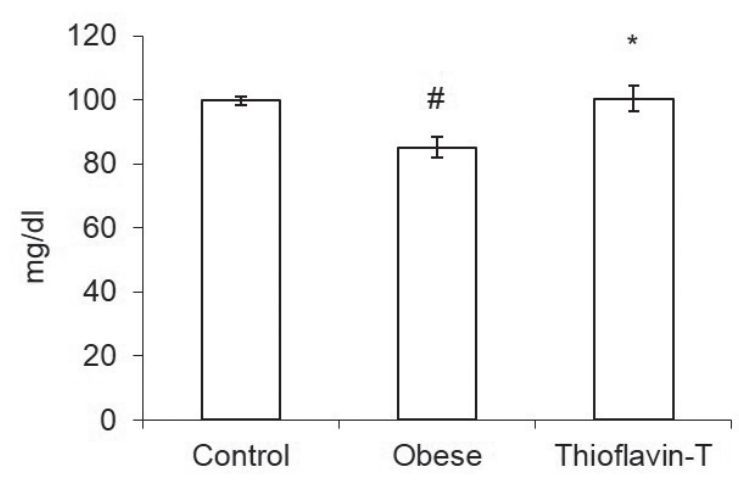

Figure 4. Serum triglycerides (a), cholesterol (b) and HDL (c) levels in the control, untreated obese, and ThT-treated mice (shown as Thioflavin-T in the graph). Data is shown as mean $\pm S D$. (a): ${ }^{*} p<0.05$ compared with the control group; (b): \#\# $p<0.01$ compared with the control group. ${ }^{* *} p<0.01$ compared with the obese group; $(c): \# p<0.05$ compared with the control group. ${ }^{*} p<0.05$ compared with the control group.

the increase of ALT levels was significant in comparison with the control group (Fig. 2). Upon treatment with ThT, ALT levels were significantly decreased ( $p<0.05$, Fig. 2b).

\section{Adipokines}

In comparison with the control group, the untreated obese mice showed no significant change in adiponectin levels, while there was a significant increase in their leptin levels ( $p<0.001$ ) (Fig.3a and b). Upon eight-week administration of ThT, adiponectin levels changes were not significant compared with obese mice ( $p>0.05$ ), (Fig. 3a). On the other hand, ThT was able to significantly lower leptin concentrations compared to the untreated obese group $(p<0.001)$ (Fig.3b).

\section{Lipids}

The serum triglyceride (TG) and cholesterol levels of the untreated obese group were found to be significantly higher compared with the control group $(p<0.05$, and $p$ $<0.01$ respectively), while HDL levels were significantly lower $(p<0.05)$ (Fig.4). ThT treatment had a significant effect in lowering cholesterol and increasing HDL levels

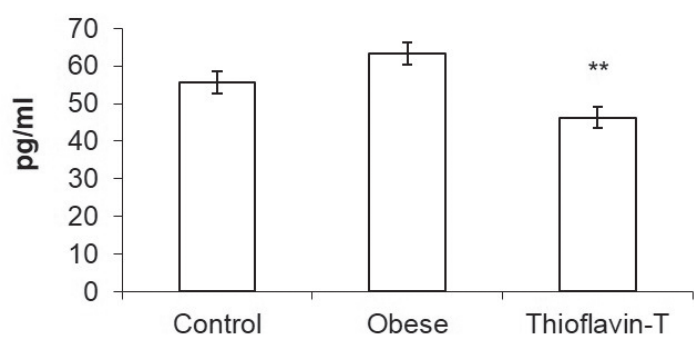

Figure 5. Serum TNF- $\alpha$ levels in the control, untreated obese, and ThT-treated mice (shown as Thioflavin-T in the graph). Data is shown as mean $\pm S D$. ${ }^{* *} p<0.01$ compared with the obese group.

of the treated obese group (Fig.4B and C), but not in triglyceride levels (Fig.4A).

\section{TAC and TNF $=\alpha$}

Total antioxidant capacity did not change significantly in the untreated obese mice compared with the control group, and ThT administration had no significant effect on this parameter either ( $p>0.05$, results not shown). It should be pointed out that the gavage procedure is stress- 


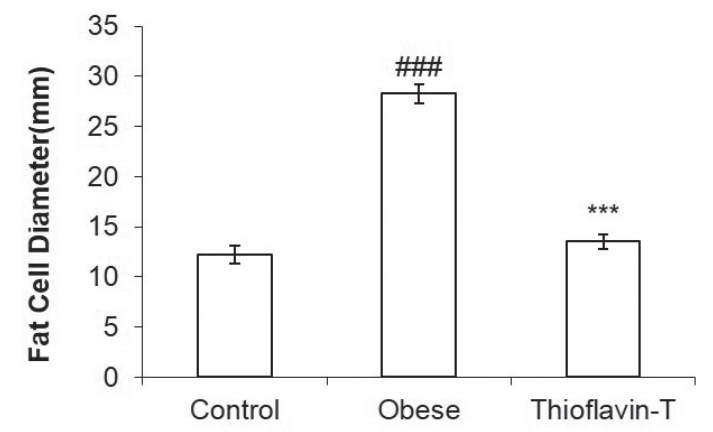

Figure 6. Mean diameter of adipocytes taken from abdominal adipose tissue in control, untreated obese, and ThT-treated mice; data is shown as the mean $\pm S D$, and \#\#\#p<0.0001 compared with the obese group; ${ }^{* * *} p<0.0001$ compared with the obese group.

ful and may affect antioxidant levels, and to obtain more accurate results, a comparison with an untreated group is needed which would receive a placebo by gavage.

Finally, the TNF- $\alpha$ inflammatory factor could be significantly decreased upon treatment with ThT (Fig. 5).

\section{Histological Studies Adipocytes}

Compared with the control group, the untreated obese mice show lager adipocytes $(p<0.0001)$ (Fig.6), while upon treatment with ThT, adipose cells diameter is significantly reduced compared with the untreated group $(p$ $<0.0001)$.

\section{Hepatocytes}

The result of Hematoxylin- Eosin $(\mathrm{H} \& \mathrm{E})$ staining of the mice hepatocytes is shown in Fig.7 a-c. Obese animals show lipid droplets and multinucleate cells and the overall structure appears to be disordered in comparison with healthy animals. Treatment with ThT has a beneficial effect on liver cells and is also able to reduce the lipid droplets.

\section{DISCuSSION}

Consumption of a high fat diet results in the disruption of the normal lipid profile, as well as hyperglycemia and increase of cytokines that would contribute to an inflammatory state (13). Appearance of a fatty liver that is infiltrated by macrophages is another deleterious consequence that could be mimicked in animal models with the use of palatable food that leads to the animals hyperphagia (14). A similar state was observed in our high fat fed model, where accordingly, a higher weight gain had occurred, as well as abnormality in related biochemical parameters and adipokines.

Thioflavin $\mathrm{T}$ is a benzothiazole dye that is widely used as a mean to characterize amyloid structures; it is proposed to exert its effect by binding to cavities found in the fibrils structures (15), but has also been observed to have the potential for making more specific interactions with amyloid forming proteins precursors (16), as well as albumin (17). These recent findings are suggestive of the potential of ThT as a ligand which may act via specific interactions with macromolecular targets.

In the current study, ThT was shown to reduce the body weight of high-fat fed animals, correct their lipid profile, and lower their blood glucose levels. In a previous study on diabetic rats, similar effects had been observed (10). Since ThT-treated animals showed lower levels of serum alpha-amylase, and a slight in vitro inhibitory effect had also been observed for ThT toward alpha-amylase enzyme (10), the current findings on blood glucose levels and weight may be partly attributed to this property of ThT. In fact, glucosidase inhibitors may be beneficial in the "diabesity” state, by lowering postprandial glucose levels $(18,19)$ and helping in weight loss $(20,21)$. Alphaamylase inhibitors have been observed to positively affect disturbed lipid profiles too (22). ThT is also hypothesized to have an appetite suppressing effect (10).

Liver function markers AST and ALT that were altered as a result of high fat diet consumption in mice were decreased upon treatment with ThT, and accordingly, liver tissue disruption and accumulation of fat droplets in hepatocytes was also ameliorated by the compound. It is interesting to mention that reports on acarbose (a glucosidase inhibitor) have shown its potential in the treatment of hepatosteatosis (23). The benzothiazole core has been used as a starting point to synthesize various derivatives with diverse biological properties including antitumor,
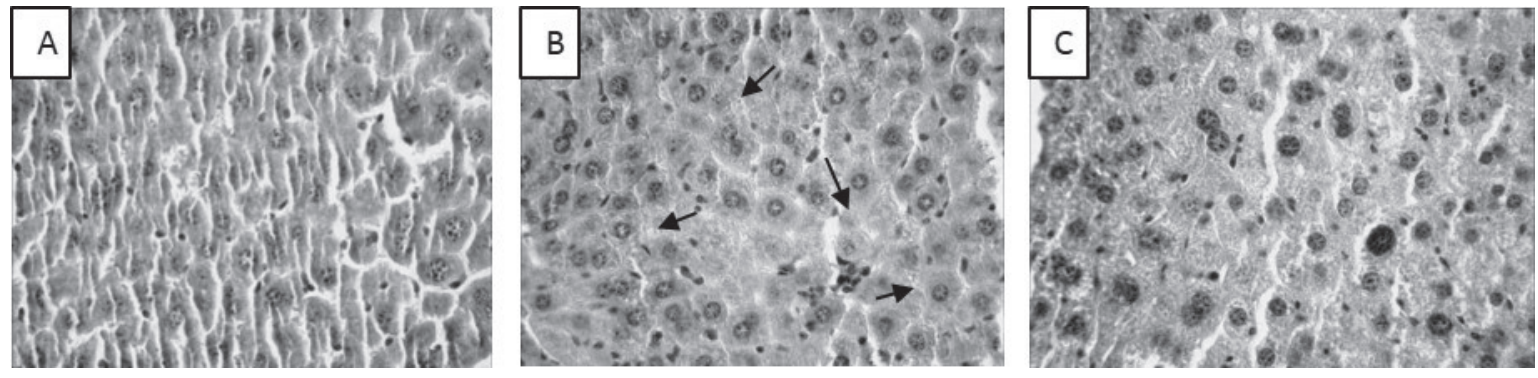

Figure 7. Representative HङE stained sections of liver tissue from control (a), obese (b), and ThT-treated group. Arrows point to fat droplets. 
antimicrobial, antihelmintic, antioxidant, and anti-inflammatory ones (24). These derivatives, which show a variety of structures, act on a range of different targets, including enzymes that may be of importance in a particular disease. As an example, the anti-inflammatory activity of benzothiazoles could be related to their property as inhibitors of cyclooxygenase and lipooxygenase enzymes $(25,26)$. In the current study, ThT has been observed to have antioxidant and antinflammatory properties to some extent, and further act on the adipose tissue too. The significant effect of ThT on leptin is specially of interest, with regard to the importance of this adipokine in weight regulation (27). Recently proposed antiobesity compounds that act on accumulation of visceral fat have also been observed to influence leptin levels (28), (29), (30).

\section{CONCLUSIONS}

Thioflavin $\mathrm{T}$, the benzothiazole dye that is widely used for its ability to interact with amyloid fibrils, has been shown to possess an antiobesity potential. High fat-fed mice that were treated with ThT underwent weight loss, change in adipocyte size and decrease in liver accumulated fat, that were accompanied with a correction of blood glucose levels and lipid profile. Furthermore, ThT effect comprised an antioxidant and anti-inflammatory component, alongside with a regulation of adipokine levels. With regard to the potential of benzothiazoles to exert various biological roles, it is suggested that ThT could be considered as a candidate core compound against diabetes and obesity, whose derivatives may be worth of study in these pathologic conditions.

Acknowledgments: This project has been supported by a grant from the Endocrinology and Metabolism Research Institute (EMRI) of Tehran University of Medical Sciences (Project number: 1391-01-106-1486).

\section{REFERENCES}

1. WALI JA, THOMAS HE, SUTHERLAND AP 2014 Linking obesity with type 2 diabetes: the role of T-bet. Diabetes Metab Syndr Obes 7:331-40. http://dx.doi.org/10.2147/DMSO.S51432

2. NAKAMURA K, FUSTER JJ, WALSH K 2014 Adipokines: a link between obesity and cardiovascular disease. J Cardiol 63 (4): 250-259. http://dx.doi.org/10.1016/j.jjcc.2013.11.006

3. Heshmat R, Larijani FA, Pourabbasi A, Pourabbasi A 2014 Do overweight students have lower academic performance than their classmates? A pilot cross sectional study in a middle school in Tehran. J Diabetes Metab Disord 13:87. http://dx.doi.org/10.1186/s40200-014-0087-0

4. BRUMPTON B, LANGHAMMER A, ROMUNDSTAD P, CHEN Y, MAI XM 2013 The associations of anxiety and depression symptoms with weight change and incident obesity: The HUNT Study. Int J Obes 37 (9): 1268-74.

http://dx.doi.org/10.1038/ijo.2012.204
5. FRANKS PW, HANSON RL, KNOWLER WC, SIEVERS ML, BENNETT PH, LOOKER HC 2010 Childhood obesity, other cardiovascular risk factors, and premature death. N Engl J Med 362 (6): 485-93. http://dx.doi.org/10.1056/NEJMc1002801

6. LEE C, WOO Y, WANG Y, YEUNG C, XU A, LAM K 2014 Obesity, adipokines and cancer: An update. Clin Endocrinol (Oxf) 83 (2): 147-156. http://dx.doi.org/10.1111/cen.12667

7. AL-KALBANI M, BURNEY IA 2014 The Epidemics of Obesity and Cancer: No simple remedy. Sultan Qaboos Univ Med J 14 (3): e294-6. http://www.ncbi.nlm.nih.gov/pmc/articles/PMC4117652/ pdf/squmj1403-e294-296.pdf

8. HANIF MW, KUMAR S 2002 Pharmacological management of obesity. Expert Opin Pharmacother 3 (12): 1711-1718. http://dx.doi.org/10.1517/14656566.3.12.1711

9. RYAN DH 2014 The pharmacological and surgical management of adults with obesity. J Fam Pract 63(7):S21-6.

10. NAJAFIAN M, AMINI S, DEHESTANI B, PARIVAR $K$, EBRAHIM-HABIBI A 2015 Thioflavin T effect in diabetic Wistar rats: Reporting the antihyperglycemic property of an amyloid probing dye. Pharmacol Rep 67 (2): 364-369. http://dx.doi.org/10.1016/j.pharep.2014.10.013

11. KUZNETSOVA IM, SULATSKAYA AI, UVERSKY VN, TUROVEROV KK 2012 Analyzing thioflavin T binding to amyloid fibrils by an equilibrium microdialysis-based technique. PLoS One 7 (2): e30724. http://dx.doi.org/10.1371/journal.pone.0030724

12. BANAKAR F, PARIVAR K, YAGHMAEI P, MOHSENIKOUCHESFEHANI H 2013 The effects of embryo/neonate exposure to Orlistat in NMRI-mouse strain. Ann Biol Res 4 (6): 300-311.

13. LEE CY 2013 The Effect of high-fat diet-induced pathophysiological changes in the gut on obesity: what should be the ideal treatment \& quest. Clin Transl Gastroenterol 4 (7): e39. http://dx.doi.org/10.1038/ctg.2013.11

14. SAMPEY BP, VANHOOSE AM, WINFIELD HM, FREEMERMAN AJ, MUEHLBAUER MJ, FUEGER PT, NEWGARD CB, MAKOWSKI L 2011 Cafeteria diet is a robust model of human metabolic syndrome with liver and adipose inflammation: comparison to high-fat diet. Obesity 19 (6): 1109-17. http://dx.doi.org/10.1038/oby.2011.18

15. GROENNING M, NORRMAN M, FLINK JM, VAN DE WEERT M, BUKRINSKY JT, SCHLUCKEBIER G, FROKJAER S 2007 Binding mode of Thioflavin T in insulin amyloid fibrils. J Struct Biol 159 (3): 483-97. http://dx.doi.org/10.1016/j.jsb.2007.06.004

16. COELHO-CERQUEIRA E, PINHEIRO AS, FOLLMER C 2014 Pitfalls associated with the use of Thioflavin-T to monitor anti-fibrillogenic activity. Bioorg Med Chem Lett 24 (14): 3194 3198. http://dx.doi.org/10.1016/j.bmcl.2014.04.072

17. SEN P, FATIMA S, AHMAD B, KHAN RH 2009 Interactions of thioflavin T with serum albumins: spectroscopic analyses. Spectrochim Acta A Mol Biomol Spectrosc 74 (1): 94-99. http://dx.doi.org/10.1016/j.saa.2009.05.010

18. LI Y, WEN S, KOTA BP, PENG G, LI GQ, YAMAHARA J, ROUFOGALIS BD 2005 Punica granatum flower extract, a potent alpha-glucosidase inhibitor, improves postprandial hyperglycemia in Zucker diabetic fatty rats. J Ethnopharmacol 99 (2): 23944. http://dx.doi.org/10.1016/j.jep.2005.02.030

19. PRISCILLA DH, ROY D, SURESH A, KUMAR V, THIRUMURUGAN K 2014 Naringenin inhibits alpha-glucosidase activity: a promising strategy for the regulation of postprandial hyperglycemia in high fat diet fed streptozotocin induced diabetic rats. Chem Biol Interact 210: 77-85. http://dx.doi.org/10.1016/j.cbi.2013.12.014 
20. HAMADA Y, NAGASAKI H, FUCHIGAMI M, FURUTA S, SEINO Y, NAKAMURA J, OISO Y 2013 The alpha-glucosidase inhibitor miglitol affects bile acid metabolism and ameliorates obesity and insulin resistance in diabetic mice. Metabolism 62 (5): 734-42. http://dx.doi.org/10.1016/j.metabol.2012.10.015

21. PREUSS HG 2009 Bean amylase inhibitor and other carbohydrate absorption blockers: effects on diabesity and general health. J Am Coll Nutr 28 (3): 266-276.

http://dx.doi.org/10.1080/07315724.2009.10719781

22. NAJAFIAN M, EBRAHIM-HABIBI A, YAGHMAEI P, PARIVAR K, LARIJANI B 2010 Core structure of flavonoids precursor as an antihyperglycemic and antihyperlipidemic agent: an in vivo study in rats. Acta Biochim Pol 57 (4): 553-560.

23. OKADA K, YANAGAWA T, WARABI E, YAMASTU K, UWAYAMA J, TAKEDA K, UTSUNOMIYA H, YOSHIDA H, SHODA J, ISHII T 2009 The alpha-glucosidase inhibitor acarbose prevents obesity and simple steatosis in sequestosome 1/A170/p62 deficient mice. Hepatol Res 39 (5): 490-500. http://dx.doi.org/10.1111/j.1872-034X.2008.00478.x

24. CHAUDHARY P, SHARMA PK, SHARMA A, VARSHNEY J 2008 Recent advances in pharmacological activity of benzothiazole derivatives. Int J Curr Pharm Res 2(4):5-11.

25. GERONIKAKI A, HADJIPAVLOU-LITINA D, AMOURGIANOU M 2003 Novel thiazolyl, thiazolinyl and benzothiazolyl Schiff bases as possible lipoxygenase's inhibitors and anti-inflammatory agents. Il Farmaco 58 (7): 489-95. http://dx.doi.org/10.1016/S0014-827X(03)00065-X
26. SHAFI S, MAHBOOB ALAM M, MULAKAYALA N, MULAKAYALA C, VANAJA G, KALLE AM, PALLU R, ALAM MS 2012 Synthesis of novel 2-mercapto benzothiazole and 1, 2, 3-triazole based bis-heterocycles: Their anti-inflammatory and antinociceptive activities. Eur J Med Chem 49: 324-33. http://dx.doi.org/10.1016/j.ejmech.2012.01.032

27. BORER KT 2014 Counterregulation of insulin by leptin as key component of autonomic regulation of body weight. World J Diabetes 5 (5): 606-629. http://dx.doi.org/10.4239/wjd.v5.i5.606

28. HWANG JT, KIM SH, HUR HJ, KIM HJ, PARK JH, SUNG MJ, YANG HJ, RYU SY, KIM YS, CHA MR, KIM MS, KWON DY 2012 Decursin, an active compound isolated from Angelica gigas, inhibits fat accumulation, reduces adipocytokine secretion and improves glucose tolerance in mice fed a high-fat diet. Phytother Res 26 (5): 633-638. http://dx.doi.org/10.1002/ptr.3612

29. SONG MY, LV N, KIM EK, KWON KS, YOO YB, KIM JH, LEE SW, SONG JH, LEE JH, LEE SK, SHIN BC, RYU DG, PARK BH, KWON KB 2009 Antiobesity activity of aqueous extracts of Rhizoma Dioscoreae Tokoronis on high-fat diet-induced obesity in mice. J Med Food 12 (2): 304-349.

http://dx.doi.org/10.1089/jmf.2008.1010

30. OZCELIK O, DOGAN H, KELESTIMUR H 2004 Effects of a weight-reduction program with orlistat on serum leptin levels in obese women: A 12-week, randomized, placebo-controlled study. Curr Ther Res Clin Exp 65 (2): 127-37. http://dx.doi.org/10.1016/S0011-393X(04)90025-2 
